\title{
nature
}

\section{Rules of genome access}

Statements by presidents of countries and societies highlight the concern that human genome data be publicly accessible, and quickly. The devil may lie in the emerging terms of public access to privately owned databases.

A s many commentators have noted, there is less than meets the eye in the content of recent statements by President Bill Clinton and Prime Minister Tony Blair that the raw data from human genome projects should be released rapidly into the public domain. But they affect the climate in which decisions over patents and investment are taken. Now the presidents of the National Academy of Sciences and of the Royal Society have issued a joint statement in this week's issue (see page 325) urging that the human genome sequence "must be freely available to all humankind", and that patents should only be awarded to applications in which significant utility is demonstrated.

The principal, if unmentioned, target of these concerns is Celera Genomics, the private rival of the publicly funded human genome project. The existence of the public project is a guarantee against a potentially catastrophic monopoly situation. Celera's financial interests lie in its combination of intellectual property derived from genes and their variability, and from charging subscribers for access to software that accurately pulls out genes and makes good predictions of function by integrating information from a range of sources, including sequence homologies in different databases and relevant literature. The value of such services is reflected in the $\$ 283$ million acquisition by Celera of the software company Paracel.

But what are Celera's terms of access? In statements to Nature, the company has promised that academic researchers will have free access at the time of publication - some months after subscribers get unconditional access - to the primary sequence data from its website, or on DVD, without any restriction, and can publish and seek patents on discoveries without any 'reach through' rights (see page 324). Anyone, except competitors, will be able, for example, to use the data to develop DNA chips, it claims.

The sticking point is annotation - the identification of gene sequences and assigning probable function. Traditionally, researchers have annotated sequences and made the results available freely. But it appears that Celera would not allow researchers who are not subscribers to take the whole genome, annotate it and distribute it in competition. This restriction appears unreasonable, given that the challenge of making good predictions of function is in the software and not in the sequence itself.

Celera's ambitions highlight the potentially changing rules of the game of databases. There is every possibility that large data sets will increasingly be held by privately funded ventures.

Nature's policy is that human sequence data should be deposited in a reliable, publicly available, unrestricted and free database. GenBank and its equivalents in Europe and Japan satisfy those conditions. But there is no insistence in principle that deposition be in databases that are publicly funded - the conditions of access and the community's confidence in the long-term sustainability and accessibility of the database are what count. The value of databases such as GenBank lies partly in their role as an honest broker of information for the community at large, and any private owner of a database would do well to have earned a strong reputation in that respect too.

\section{Eyes, ears and science}

Two artists have succeeded in involving two or more senses to produce something special.

$\mathrm{M}$ ost of us are likely to approach new art in ignorance of current aesthetic theories and trends and of the artist's previous output, in the hope that it will speak to us or at least grip our attention. Statistically, this hope is likely to be forlorn — innovative artists with an ability immediately to communicate beyond the cognoscenti are a minority in any generation. It's surprising and rewarding, therefore, to encounter artists working in unconventional media who make one sit up and take notice.

Two such artists are Carsten Nicolai, based in East Berlin, and the Danish artist Ann Lislegaard, who have recently exhibited at the Museum of Modern Art in Oxford, UK, and have also exhibited widely in the United States and elsewhere in Europe. The Oxford exhibition focused on works combining sound and vision, and these two artists made an impact for reasons associated with science.

Lislegaard's In another room consists of a large white wall towards which is pointed a 500-watt white halogen light. A recording of two people - a man moving around in a room, a woman describing his actions - plays softly in the background. The light illuminates the wall with a rapidly varying intensity proportional to that of the sound. This leads to an effect that challenges one's sense of orientation. Whatever the neural mechanisms at work, contemplating the wall for sever- al minutes produces sensations that are unexpected and memorable.

The interest in Nicolai's Atem is less perceptual - it is directly related to known physics - but is still striking and even beautiful. A raised wooden floor has eight large speakers embedded in it, all sounding quietly at slightly different low frequencies - a few hertz - generating both an audible and vibrational effect on the onlooker. The frequencies are shifted slowly, and the envelope of sound amounts to a gradually changing pattern of pulsation, only just discernible as such. But Nicolai places two large glass flasks on the floor, illuminated at an angle by a spotlight. The floor's motion is picked up by water in the flasks, which refract the light onto the floor in a pattern affected by the water waves set up by the vibrations. As the audible frequencies shift, the patterns of light exhibit slowly changing networks of cusps of illumination similar to, but much more fascinating than, those sometimes seen on a swimming-pool floor in bright sunlight. Again, the cumulative effect, drawing on three of the senses, is more than the sum of the parts, each of which is striking in itself.

These works deserve wide exposure, and could in principle be easily replicated in galleries and science museums. But are they works of art or sophisticated, science-based entertainment? That question is left as an exercise for the reader, best answered only after experiencing them. 